\title{
The Economics of Child Custody
}

\author{
By IMRAN RASUL \\ University of Chicago and CEPR
}

Final version received 1 November 2004.

\begin{abstract}
I develop a model of marriage in which spouses decide on investments in child quality during marriage, and on the allocation of child custody should they divorce. The custodial allocation determines the share of the marital surplus each spouse appropriates, which in turn influences spouses' investment incentives. The custodial allocation therefore has both distributional and efficiency consequences. I derive the equilibrium investments and optimal custodial allocation, and identify three channels through which making divorce easier affects child welfare: investments in child quality during marriage, the likelihood of divorce, and the allocation of custody if divorce occurs.
\end{abstract}

\section{INTRODUCTION}

The structure of the American family has changed dramatically in the last thirty years. In 1970 around half of all households comprised an employed father, a homemaker mother and children; the figure today is less than one in five. One important reason for this change is the rise in divorce. Over a million children are now involved in divorce each year (Bumpass et al. 1995).

Economists have focused largely on the consequences of marital breakdown for adult and child welfare, and on the design and effect of policies related to divorcees and their children. However, one aspect of divorce has remained largely neglected in the economics literature: the allocation of child custody. The main contribution of this paper is to fill that void. ${ }^{1}$

This paper develops a model of bargaining within marriage in which spouses make two decisions: how much to each invest in child quality during marriage, and how to allocate child custody should they divorce. Child quality is viewed as a household public good, and parents have heterogeneous valuations of child quality.

The ex post allocation of custody influences the share of the marital surplus that each spouse is able to appropriate, which in turn determines each spouses' ex ante investment incentives. Hence the allocation of custody has both distributional and efficiency consequences within marriage.

Two features of marriage are emphasized. First, spouses are unable to specify the investments in child quality they will make during marriage, as part of any marital contract. This is because such investments are non-verifiable to third parties outside of the household. Hence spouses behave opportunistically and renegotiate over the division of the marital surplus even after investments are sunk. This provides a straightforward application of the recent property rights literature to household behaviour.

Second, the probability of divorce is endogenously determined by parental investments themselves. Since the return to investing in child quality is assumed to be greater in marriage than in divorce, by investing spouses increase the 
surplus from marriage over divorce, thereby reducing the likelihood of marital breakdown, all else equal.

The allocation of child custody is modelled as being decided ex ante as part of the marital contract. This allocation of custody maximizes spousal investments into child quality and minimizes the probability of divorce, all else equal. If child welfare increases in parental investments or decreases when parents break up, then determining the allocation of custody ex ante is consistent with the prevailing legal doctrine of allocating custody in the 'best interests of the child'. Hence the paper provides a normative analysis on the allocation of custody.

Of course, in reality parents may actually decide the allocation of custody only after divorce has occurred. This is a complex problem, involving parents simultaneously bargaining over custody, transfers, property and so forth. The approach taken in this paper is to develop a tractable framework in which to think through how custody ought to be allocated in the child's best interests. This provides a benchmark from which to evaluate how far such ex post bargaining may lead to custodial allocations diverging from what is actually in the child's best interests.

The main results are as follows. First, on the optimal allocation of custodial rights, the analysis highlights two effects. On the one hand, because child quality is a public good, spouses prefer the parent that values child quality the most to have sole custody ex post. This gives the high-valuation parent the greatest incentives to invest within marriage, and leaves both parents better off. On the other hand, as divorce occurs with positive probability, both parents prefer to have more own custody to maximize the returns on their own investment in divorce.

I show that, for couples with relatively homogeneous valuations of child quality, joint custody is optimal with the high-valuation spouse having the majority share. ${ }^{1}$ Couples with relatively heterogeneous valuations prefer the high-valuation parent to have sole custody. The ex post efficient allocation of custody - giving sole custody to the high-valuation parent - therefore maximizes ex ante investment incentives only if the degree of heterogeneity in spousal valuations of child quality is sufficiently high.

Second, joint custody is more likely to be optimal when divorce costs are low. As divorce costs fall the couple are less likely to remain married, so spouses are better off shifting custody away from the high-valuation spouse. Doing so maximizes the marital surplus to be bargained over, leaving both spouses better off. Although lower divorce costs shift the optimal custodial allocation towards the low-valuation spouse, the high-valuation spouse always retains the majority custodial share.

This provides a basis for understanding how two significant trends in family structure over the last generation - the rise in the incidence of joint custody, and legal changes promoting fathers' custodial rights - relate to the fall in divorce costs over the same period.

The paper also speaks directly to the debate on the effect of making divorce easier on child welfare. A raft of pro-marriage policies have recently been introduced in the United States, some of which are explicitly designed to increase divorce costs. This model makes precise three channels through which divorce costs affect child welfare. 
First, lower divorce costs make divorce more likely, all else equal, and this may lower child welfare for those children whose parents divorce.

Second, conditional on divorce, joint custody is more likely to be optimal when divorce costs fall, so that children retain contact with both parents. This may improve child welfare in divorce.

Third, for a given population of married couples, making divorce easier leads to higher levels of investment during marriage, all else equal. This is because, with low divorce costs, the marginal impact of investments on the probability of the marriage remaining intact is greater.

Contrary to intuition, lowering divorce costs will generally have conflicting general equilibrium effects on child welfare.

The paper is organized into five sections. Section I discusses related literature. Section II develops the model and solves for the Nash equilibrium investment levels, and the optimal allocation of custodial rights. Section III analyses how custody and investment relate to divorce costs, and Section IV concludes. All proofs are in the Appendix.

\section{RELATED LITERATURE}

By applying contract theory to the household, this paper builds a bridge between the property rights literature (Grossman and Hart 1986; Hart and Moore 1990) (henceforth GHM) and models of household behaviour.

In the standard GHM environment, two parties invest in a private good. These investments cannot be ex ante specified, hence parties Nash-bargain over the surplus from the relationship after investments have been sunk. In this model, having ex post ownership of the good improves an investor's bargaining power within the relationship.

Two robust results emerge from the baseline GHM model. First, parties are unable to appropriate the full returns on their own investment because of this renegotiation ex post; hence ex ante investment incentives are reduced below the first-best level. Second, it is generally optimal for one investor to have sole ownership based on some technological advantage.

Extensions to this model show that joint ownership can be optimal when some part of investment is embodied in physical assets rather than human capital (Hart 1995), when reputational concerns exist (Halonen 2002), when alternative bargaining rules are used (de Meza and Lockwood 1998) or if ownership induces greater specialization (Rajan and Zingales 1998).

Besley and Ghatak (2001) extend the GHM framework to the situation where investments are made into a public good. They show that the public good is optimally owned by whichever party values the public good the most. Hence allocating property rights ex post efficiently also maximizes ex ante investment incentives, so that joint ownership is generally suboptimal.

This paper extends the analysis of Besley and Ghatak (2001) in two directions in the context of spousal investments in child quality. First, parents (investors) can choose from a continuum of ex post custodial schemes. Second, the probability of marital breakdown is positive and is endogenously determined by the level of parental investments. 
The model here establishes that if divorce occurs with positive probability, then (i) the ex post efficient allocation of custody maximizes ex ante investment incentives only if spousal valuations of child quality are sufficiently heterogeneous; (ii) for couples with relatively homogeneous valuations, joint custody is optimal; (iii) the high-valuation spouse always has the majority custodial share.

In addition, the model highlights that with endogenous divorce, (i) parents have less incentives to have more own custody, as this reduces the importance of their investment in keeping the marriage intact: this shifts the allocation of custody towards the high-valuation parent and makes joint custody less likely, all else equal; (ii) this effect is stronger for parents with a higher joint valuation of child quality.

In keeping with the property rights literature, the allocation of custody has both efficiency and distributional consequences. However, in contrast with that literature, because in this model the probability of divorce is endogenously determined, Nash equilibrium investments may be above the first-best level. The intuition is straightforward. With endogenous divorce, an additional incentive to invest arises because this reduces the likelihood of divorce. I show that Nash equilibrium investments are more likely to be above the surplusmaximizing level if child quality is more of a marital-specific asset.

These results are in contrast to standard models of household behaviour, such as the unitary (Becker 1991) and Nash bargaining models (McElroy and Horney 1981; Chiappori 1988), which assume household decisions to be Pareto efficient. The unitary framework assumes that spousal preferences are aligned, and so has little to say on conflicts over the allocation of custody. In Nash bargaining models, custody determines the threat point in marital bargaining, and so has only distributional consequences.

The model developed here still however retains a number of features in common with the literature on household decision-making-parents value child quality (Willis 1973; Becker 1991) parents invest in their children (Becker and Tomes 1986; Mulligan 1997) and parents bargain the marital surplus (Chiappori 1988; Lundberg and Pollak 1993).

Three papers in the literature relate closely to this one. Weiss and Willis (1985) consider a model of married couples, where the allocation of custody is also determined ex ante. They consider only sole custody, and they determine the set of Pareto-efficient transfers in divorce. They assume that all allocations in marriage can be contracted upon, so the allocation of custody has no consequences for efficiency.

Brown and Flinn (2001) present a structural dynamic model of parental investments in children across marital states and empirically examine the effects on investment of different given custodial arrangements. Their model has the feature that divorce occurs endogenously, but parents choose only investments, not custody, and these investments can be specified ex ante.

Francesconi and Muthoo (2003) have independently developed a model of child custody that shares many features of this paper. They also extend the Besley-Ghatak (2001) framework to derive the optimal ex ante allocation of custody and investment incentives within marriage. They analyse in more detail the relation between custody and the technology of producing child quality. Not all of their results are in line with those here. For example, they establish 
conditions under which it is optimal for the low-valuation spouse to have sole custody. The key features that drive the differences in results between this paper and theirs are: (i) that they assume a zero probability of divorce, and (ii) that they allow parental valuations of child custody to differ across marital states. Given that the two papers share a common approach in deriving optimal ex ante custodial allocations, they should be viewed as highly complementary. ${ }^{2}$

\section{THE MODEL}

\section{The setup}

The household comprises a married husband $(h)$ and wife $(w)$, with one child. ${ }^{3}$ Spouse $i$ 's payoff in marriage is quasi-linear in a private gain from marriage, $v_{i}$, a private consumption good, $x_{i}$, and the benefits from child quality, $u(q)$;

$$
U_{i}^{M}=v_{i}+x_{i}+\theta_{i} u(q)
$$

The parameter $\theta_{i} \geqslant 0$ is $i$ 's observable valuation of the benefits from child quality. Husband and wife may therefore value child quality to differing degrees.

The private gain from marriage, $v_{i}$, is randomly drawn from a known distribution. This gain is unknown to either spouse at the time of marriage, but is realized during marriage. ${ }^{4}$

Income, $y_{i}$, is allocated over the private consumption good and child quality investments. Normalizing the price of the private consumption good to one, and assuming a constant marginal cost of child quality, $p$, spouse $i$ 's budget constraint is $y_{i}=x_{i}+p q_{i}$.

Each spouse makes a sunk investment into child quality during marriage. This investment can be interpreted as the provision of time and resources into child development. Child quality is a household public good in that it generates benefits that are non-rival and non-excludable to husband and wife.

Let $q=\left(q_{h}, q_{w}\right)$ denote the vector of parental investments into child quality, so $u(q)$ denotes the benefits in marriage of making these investments. These benefits are assumed to be concave, continuous and twice differentiable in each investment, with $u(q)$ satisfying the Inada endpoint conditions and parental investments being weak complements, so that $\partial^{2} u\left(q_{i}, q_{j}\right) / \partial q_{\underline{i}}, \partial q_{1} \geqslant 0$ for $i \neq j$. This last assumption ensures that, consistent with the literature on child welfare within families, it will be optimal for both parents to make positive investments into child quality in equilibrium. In line with Becker's $(1973,1974)$ original theory of marriage, it is also consistent with the positive assortative matching of couples by the productivity of their investments into child quality.

\section{First best}

Consider a benchmark world in which spouses can specify investments during marriage as part of the marital contract; divorce never occurs; and spouses choose their investments cooperatively to maximize the joint surplus from marriage. The vector of joint surplus maximizing investments, $q^{*}=\left(q_{h}^{*}, q_{w}^{*}\right)$, 
solves

$$
\max _{\left\{q_{h}, q_{w}\right\}} U_{h}^{M}+U_{w}^{M}=\sum_{i \in\{h, w\}}\left(v_{i}+y_{i}+\theta_{i} u(q)-p q_{i}\right) .
$$

The first-best level of investments are defined by the following pair of equations:

$$
\left(\theta_{h}+\theta_{w}\right) \frac{\partial u\left(q^{*}\right)}{\partial q_{i}}=p, \quad \text { for } i=h, w .
$$

This is the standard Lindahl-Samuelson rule for public goods provision. The level of parental conflict in valuations of child quality is irrelevant. Investments are determined by parents' joint valuation of child quality.

\section{Second best}

Now consider a more realistic setting in which spouses choose investments non-cooperatively to maximize their own expected utility. This setting diverges further from the first best in two ways.

First, spousal investments during marriage cannot be verified by third parties. Although investments are observable to both parents, their nonverifiability prevents spouses from specifying what these investments during marriage will be in a marriage contract. If spouses were to write contracts contingent on investments, then at any stage of marriage either spouse could hold up the other, claiming they had not made the agreed-to investment. No third party can verify whether each parent has undertaken the agreed-to investments. ${ }^{5}$

Hence, after investments are made, spouses renegotiate over the division of whatever marital surplus is created. Following GHM, assume that spouses Nash-bargain over the division of the marriage surplus in this renegotiation, where divorce is the relevant threat point. Both spouses retain some bargaining power at this stage, so that neither can make take-it-or-leave-it offers to their partner.

Second, divorce occurs with positive probability. Being divorced differs from being married in three ways. First, the private gains from marriage, $v_{i}$, are lost. Second, a cost of divorce, $c$, is incurred and is assumed to be equally split. This cost relates to the financial and psychic losses from divorce. Third, no further investment takes place in divorce, so income, net of previous expenditures on child investment, is allocated over the private consumption good and the divorce cost, $y_{i}-p q_{i}=x_{i}+c / 2$.

In addition, some allocation of physical custodial rights over children is enacted. Each spouse's share of physical custody is the proportion of the child's time endowment spent with them in divorce. This includes both where the child resides and the visitation rights enjoyed by the parent.

Denote the fraction of custody that goes to spouse $i$ as $\lambda_{i}$, such that $\lambda_{h}+\lambda_{w}=1$, where $\lambda=\left(\lambda_{h}, \lambda_{w}\right)$ denotes the custodial allocation. This allows for a continuum of custodial rights allocations, covering both sole and joint custody.

(C) The London School of Economics and Political Science 2006 
The payoff to spouse $i$ in divorce is then

$$
U_{i}^{D}=y_{i}+\theta_{i} \bar{u}(q, \lambda)-p q_{i}-\frac{c}{2} .
$$

In common with the earlier literature, child quality remains a public good in divorce (Weiss and Willis 1985). The benefits from child quality in divorce are however lower than in marriage, as child quality is a form of marriagespecific capital. ${ }^{6}$

Assume $\bar{u}(q, \lambda)$ to be concave, continuous and twice differentiable in each investment, satisfying the Inada endpoint conditions, with $\partial^{2} \bar{u}\left(q_{i}, q_{j}, \lambda\right) /$ $\partial q_{i} \partial q_{j} \geqslant 0$ for $i \neq j$.

A key assumption for the analysis relates to the returns to investments across marital states. This return to investment is interpreted as the formation of a lasting emotional bond between parent and child. The return to own investment is assumed to be higher in marriage than in divorce:

$$
\text { A1 } \frac{\partial u\left(q_{i}, q_{j}\right)}{\partial q_{i}} \geqslant \frac{\partial \bar{u}\left(q_{i}, q_{j}, \lambda\right)}{\partial q_{i}}>0 \text { for all } q_{j} \text { and for all } \lambda \text {. }
$$

Following the GHM literature, this is interpreted as implying that investments are partly embodied in the human capital of each parent, and thus cannot be appropriated in divorce. Hence the return on investment made during marriage falls in the absence of the other spouse, irrespective of the custodial allocation.

\section{Timing}

The timing of actions is as follows.

1. The married couple decide on the allocation of custody should they divorce.

2. Each spouse makes a non-verifiable investment into child quality, $q_{i}$.

3. Each spouse's private gain from marriage, $v_{i}$, is realized, as are the benefits from child quality. Spouses then decide whether to remain married or divorce. If they remain married, they renegotiate over the surplus created by marriage over divorce. If they divorce, each spouse pays their share of the divorce cost and the child custody arrangement is enacted.

If and when renegotiation takes place in marriage, there is symmetric information across spouses. I assume transferable utility throughout, so that couples divorce if and only if it is efficient to do so. As investments are made before the private gain from marriage is realized, the model better captures the investment incentives early in marriage. This is precisely when divorce is more likely, and furthermore, it is investments in young children that have the most permanent effects on welfare over the child's life (Danziger and Waldfogel 2000).

Natural extensions to consider include (i) embedding the framework within a marriage market model, thereby endogenizing the marriage decision; (ii) allowing for remarriage and investment across marital states; and (iii) allowing for spousal investments in their own human capital as well as into child quality. While the basic insights in the stylized model presented here are robust to these extensions, the model can be developed to also explore the impact of selection 
into marriage, life cycle behaviour and labour market participation on the outcomes studied here.

\section{Stage 3: Divorce or renegotiation in marriage}

Consider a couples' decision to remain married or to divorce. This decision takes place in stage 3 after the private gains from marriage are realized. Couples divorce if and only if it is efficient to do so. In other words divorce occurs if

$$
U_{h}^{D}+U_{w}^{D}-U_{h}^{M}-U_{w}^{M} \geqslant 0 .
$$

Substituting in (1) and (4) and rearranging, spouses remain married if the total private gains from marriage, $\phi=\left(v_{h}+v_{w}\right)$, are sufficiently large:

$$
\phi=\left(v_{h}+v_{w}\right) \geqslant-c-\left(\theta_{h}+\theta_{w}\right) \Delta(q, \lambda),
$$

where $\Delta(q, \lambda)=u(q)-\bar{u}(q, \lambda)$ are the gains from child quality in marriage over divorce. The total private gains from marriage are distributed according to a log-concave probability distribution $g(\phi)$, with support $(-\infty, \infty)$ and an associated cumulative density function $G(\phi) .{ }^{6}$ The probability of divorce is therefore

$$
G\left(\phi^{*}\right)=G\left(-c-\left(\theta_{h}+\theta_{w}\right) \Delta(q, \lambda)\right),
$$

where $\phi^{*}$ are the total private gains in the marginal marriage. ${ }^{7}$

Couples are more likely to remain married if their private gains from marriage are higher, divorce is more costly, or they undertake greater maritalspecific investments in child quality.

The probability of divorce is thus determined partly endogenously, through investments in child quality. As investment increases, as the benefits from child quality are marriage-specific, the probability of divorce falls.

Consistent with the idea that marital-specific investments reduce the likelihood of divorce, empirical evidence suggests marital dissolution is less likely if young children are present in the household, if marital duration increases or if couples have more property (Becker et al. 1977; Lillard and Waite 1991; Weiss and Willis 1997).

Suppose the couple remain married. As investments cannot be ex ante specified as part of the marital contract, the couple renegotiate over the division of the marital surplus. Following GHM, assume that couples Nashbargain over the marital surplus during this renegotiation, with equal bargaining shares and divorce as the relevant threat point. Hence the wife's Nash-bargained payoff after investments are sunk, and if it is efficient for the marriage to remain intact is:

$$
U_{w}^{M}+t^{*}=x_{w}+\frac{1}{2}\left[\phi+\left(\theta_{h}+\theta_{w}\right) u(q)+\left(\theta_{w}-\theta_{h}\right) \bar{u}(q, \lambda)\right],
$$

where $t^{*}$ is the Nash-bargained transfer from husband to wife within marriage. Spouses foresee such renegotiation when they make their investments. Hence the ex ante payoff to the wife before she invests is

$$
V_{w}(q, \lambda)=\mathbf{E}_{\phi}\left(U_{w}^{M}+t^{*} \mid \phi>\phi^{*}\right)+\mathbf{E}_{\phi}\left(U_{w}^{D} \mid \phi \leqslant \phi^{*}\right),
$$

(C) The London School of Economics and Political Science 2006 
where $\mathbf{E}(\cdot)$ is the expectations operator, and expectations are taken over the distribution of total private gains from marriage, $\phi$.

The first term in (8) is the wife's expected payoff in marriage, conditional on the marriage remaining intact. The second term is her expected divorce payoff.

The wife's expected payoff in marriage conditional on the marriage surviving is

$$
\begin{aligned}
& \mathbf{E}_{\phi}\left(U_{w}^{M}+t^{*} \mid \phi>\phi^{*}\right)= \\
& \quad x_{w}+\frac{1}{2} \int_{\phi^{*}}^{\infty} \phi g(\phi) \mathrm{d} \phi+\left(1-G\left(\phi^{*}\right)\right)\left[\left(\theta_{h}+\theta_{w}\right) u(q)+\left(\theta_{w}-\theta_{h}\right) \bar{u}(q, \lambda)\right] .
\end{aligned}
$$

Her expected payoff in divorce is

$$
\mathbf{E}_{\phi}\left(U_{w}^{D} \mid \phi \leqslant \phi^{*}\right)=G\left(\phi^{*}\right)\left(x_{w}+\theta_{w} \bar{u}(q, \lambda)-\frac{c}{2}\right) .
$$

Substituting (9) and (10) into (8) and rearranging,

$$
V_{w}(q, \lambda)=\left(x_{w}+\theta_{w} \bar{u}(q, \lambda)-\frac{c}{2}\right)+\frac{1}{2}\left[h\left(\phi^{*}\right)+\left(1-G\left(\phi^{*}\right)\right) S\right],
$$

where $h\left(\phi^{*}\right)=\int_{\phi^{*}}^{\infty} \phi g(\phi) \mathrm{d} \phi$ is the expected total private gains from marriage conditional on the marriage surviving, and

$$
S=\left(\theta_{h}+\theta_{w}\right) \Delta(q, \lambda)+c
$$

is the surplus created in marriage, net of the expected total private gains, $h\left(\phi^{*}\right)$. Equation (11) makes clear that when spouses choose their investment noncooperatively they maximize the sum of their divorce payoff and their share of the expected marital surplus conditional on the marriage remaining intact.

The following assumptions are sufficient to guarantee the existence of a pure strategy Nash equilibrium in spousal investments:

A2 $g^{\prime}\left(\phi^{*}\right)>0$

$$
\text { A3 } 1-G\left(\phi^{*}\right)>h^{\prime}\left(\phi^{*}\right)
$$

$\mathbf{A} 4 \phi^{*} \leqslant-\left[\frac{2 g\left(\phi^{*}\right)+h^{\prime \prime}\left(\phi^{*}\right)}{g^{\prime}\left(\phi^{*}\right)}\right]$.

Assumptions A2 and A3 ensure that the expected gains from marriage increase in the surplus to be bargained over. Assumption A2 implies the marginal marriage is less likely to break up if spouses invest in child quality.

Note that marriages are more likely to remain intact when either the private gains from marriage increase or investments in child quality increase. Hence the expected private gains from marriage conditional on the marriage remaining intact decline as investment increases. Assumption A3 places an upper bound on how quickly the expected private gains from marriage decline in investment. Finally, assumption A4 ensures that the expected gains from marriage are concave in each parent's investment. ${ }^{8}$ 
Proposition 1. Under assumptions A1-A4, there exists a pure strategy Nash equilibrium in spousal investments.

The Nash equilibrium investment levels diverge from the first-best level because of two sources of inefficiency. The first is a standard hold-up problem. The inability to specify investments during marriage as part of the initial marital contract leads spouses to renegotiate ex post over the division of the marriage surplus. This creates a wedge between the social and private returns on investments, as each spouse appropriates only a fraction of the return on their own investment. This lowers each spouse's ex ante investment incentives. Hence the inability to verify investments has both efficiency and distributional consequences.

The second source of inefficiency is that divorce occurs with positive probability. As the returns on investment are lower in divorce than in marriage by assumption $\mathrm{A} 1$, ex ante investment incentives are further distorted.

This inefficiency occurs despite the divorce decision itself being efficient, and the marriage surplus being efficiently divided conditional on the couple remaining married.

Stage 2: Investment in child quality I focus on the wife's investment choice to keep the exposition clear. The first-order condition for her investment choice is

$$
\begin{aligned}
\frac{\partial V_{w}}{\partial q_{w}}= & \theta_{w} \frac{\partial \bar{u}(q, \lambda)}{\partial q_{w}}+\frac{1}{2}\left[1-G\left(\phi^{*}\right)\right] \frac{\partial S}{\partial q_{w}} \\
& -\frac{1}{2} h^{\prime}\left(\phi^{*}\right) \frac{\partial S}{\partial q_{w}}+\frac{1}{2} g\left(\phi^{*}\right) \frac{\partial S}{\partial q_{w}} S=p .
\end{aligned}
$$

The wife has four sources of investment incentive. First by investing, she increases her divorce payoff. Second, she increases the surplus to be bargained if the marriage remains intact.

Third, as the benefits from child quality and the private gains from marriage are substitutable reasons why the marriage remains intact, by investing the wife lowers the expected private gains from marriage conditional on the marriage remaining intact. This acts as a disincentive to invest. ${ }^{9}$

Finally, by investing, the wife increases the probability that the marriage remains intact. This 'endogenous divorce effect' increases her investment incentives. This effect has not been considered before in the literature on nonverifiable investments. As shown later, it plays an important role in the allocation of custody, and in determining how investment incentives respond to divorce costs.

Note that, as in the first-best scenario, spouses make positive investments during marriage even if they themselves do not value child quality. This stems from their inability to specify investments as part of the marital contract, which leads them to renegotiate over the division of the marriage surplus. 
The analysis also emphasizes that both the marginal return to investment in marriage over divorce, $\partial \Delta(q, \lambda) / \partial q_{i}$, and the level of gains from child quality in marriage over divorce, $\Delta(q, \lambda)$, affect equilibrium investments.

To see how investment incentives and the allocation of custody interact, we need to specify how the returns to investment change with custody. Recall that the fraction of custody allocated to spouse $i$ is $\lambda_{i}$, such that $\lambda_{h}+\lambda_{w}=1$. The key assumption for the analysis is

$\mathbf{A 5} \frac{\partial}{\partial \lambda_{i}}\left(\frac{\partial \bar{u}(q, \lambda)}{\partial q_{i}}\right)>0$.

This says that the return to a parent's own investment is higher in divorce if that parent obtains a greater share of custody. This is because a divorced parent and child are better able to form a lasting emotional bond if they spend more time together (Becker et al. 1977).

I make the simplifying assumptions that when a parent has no contact with the child after divorce $\left(\lambda_{i}=0\right)$ the return on the investment made in marriage is zero; when they have sole custody $\left(\lambda_{i}=1\right)$ the returns are the same as in marriage; and when parents have equal custody $\left(\lambda_{i}=\frac{1}{2}\right)$ the return to each investment is the same.

As the wife obtains more custody, say, her marginal investment contributes less to the surplus created from marriage, as implied by assumption A5. Namely, $\partial \Delta(q, \lambda) / \partial q_{w}$ decreases in $\lambda_{w}$, and so the last three terms in (12) tend to zero. Crucially, when the wife has sole custody, her investment does not increase the surplus to be bargained over on the margin. The investment that maximizes her expected utility is then determined only by the return on her investment in divorce - the first term in (11).

Having considered the relation between investment and a given allocation of custody, the next section derives the ex ante optimal allocation of custody that trades off each spouse's, investment incentives to maximize total child quality and minimize the probability of divorce, all else equal.

Stage 1: The allocation of child custody At the start of a marriage, the spouses decide on the optimal allocation of custody if divorce should occur. This is in the child's best interests, as it maximizes spousal investments and minimizes the probability of divorce, all else equal.

To separately identify the effect on the optimal allocation of custody caused by a positive probability of divorce per se from the effect of divorce being endogenously determined through investments themselves, I consider two cases.

1. Child quality as a general investment Suppose the marginal returns to investment in marriage over divorce, $\partial \Delta(q, \lambda) / \partial q_{i}$, are small. Hence child quality is a general, not a marital-specific, investment, so the condition in assumption 1 holds with near equality. The probability of divorce derived in (7) is then approximately $G(-c)$. In this case the probability of divorce is determined by the realization of the total gains from marriage and the divorce cost. These are exogenous to the couple's own investment choices.

(C) The London School of Economics and Political Science 2006 
The effect of granting the wife greater custody on her investment incentives is

$$
\begin{gathered}
\frac{\partial}{\partial \lambda_{w}}\left(\frac{\partial V_{w}(q, \lambda)}{\partial q_{w}}\right) \frac{1}{2}\left(\theta_{w}-\theta_{h}\right) \frac{\partial}{\partial \lambda_{w}}\left(\frac{\partial \bar{u}(q, \lambda)}{\partial q_{w}}\right) \\
(1-G(-c))+\theta_{w} \frac{\partial}{\partial \lambda_{w}}\left(\frac{\partial \bar{u}(q, \lambda)}{\partial q_{w}}\right) G(-c) .
\end{gathered}
$$

Two factors determine the allocation of custody that maximizes investment incentives. On the one hand, as child quality remains a public good in divorce, giving custody to the high-valuation spouse increases that spouse's incentive to invest during marriage. This makes both spouses better off. This effect is captured in the first term. ${ }^{10,11}$

On the other hand, both spouses prefer to have more own custody, so that in divorce their own return on investment is maximized. This effect is captured in the second term.

Hence it is not necessarily the case that giving more custody ex post to the wife increases her ex ante investment. Investment incentives and custodial rights move together for the wife only if

$$
\frac{\theta_{w}}{\theta_{h}}>\frac{1-G(-c)}{1+G(-c)} .
$$

Both spouse's ex ante payoffs are maximized if custody is allocated to equate the marginal returns across spouses. Joint custody is then optimal if the investment incentives of both spouses increase with their own custodial share. This is true for the following non-empty set of couples: ${ }^{12}$

$$
\left\{\left(\theta_{h}, \theta_{w}\right): \frac{\theta_{w}}{\theta_{h}} \in\left[\frac{1-G(-c)}{1+G(-c)}, \frac{1+G(-c)}{1-G(-c)}\right]\right\} .
$$

Figure 1 shows the optimal allocation of custody for any given degree in heterogeneity in spousal valuations of child quality. Intuitively, the highvaluation spouse always has the majority custodial share. If one spouse values child quality sufficiently more than their partner, then both spouses' investments increase as custody is shifted towards the high-valuation spouse. Both spouses are then better off giving the high-valuation spouse sole custody in divorce. ${ }^{13}$

The set of couples for whom joint custody is optimal is largest when divorce costs are zero. As divorce costs rise the couple is more likely to remain married, so both spouses are better off, giving the high-valuation spouse greater custody. Hence for any given couple, higher divorce costs shift the optimal custodial allocation towards the high-valuation spouse. Across the population of married couples, the likelihood that any given couple finds it optimal to share custody decreases in divorce costs. These effects are also shown on Figure 1.

In the limiting case of infinite divorce costs, spouses are concerned only to allocate custody to maximize their share of the marital surplus, as the marriage 


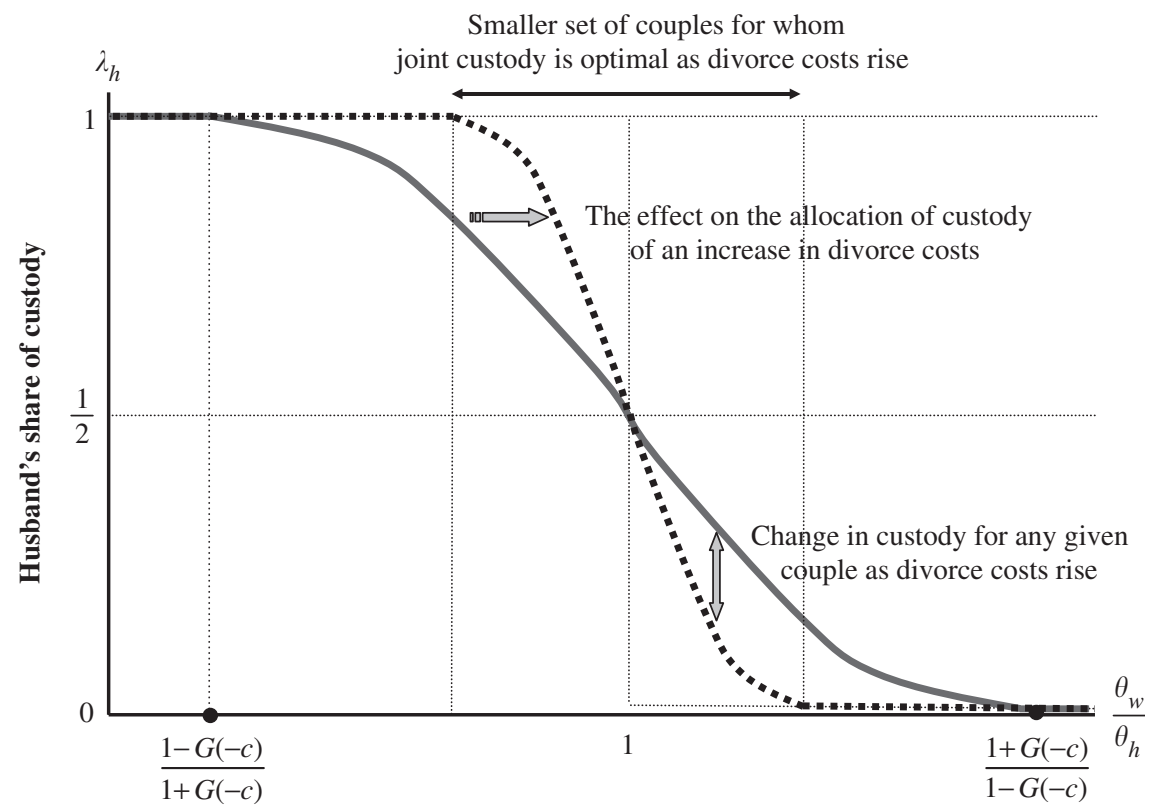

Heterogeneity in valuations of child quality

FIGURE 1. The optimal allocation of custody.

definitely remains intact. Both spouses therefore find it optimal to grant sole custody to the high-valuation spouse.

Proposition 2. If child quality is a general investment, then: (i) for couples with relatively heterogeneous valuations, the high-valuation spouse optimally has sole custody; for couples with relatively homogeneous valuations, joint custody is optimal; (ii) the set of couples for whom joint custody is optimal decreases in divorce costs; (iii) the high-valuation parent's custodial share increases in divorce costs.

This framework provides a basis for understanding how the widely perceived fall in divorce costs over the last generation relates to two significant trends in family structure over the same period: the rise in the incidence of joint custody, and legal changes promoting fathers' custodial rights. More controversially, the last proposition makes clear that a legal presumption in favour of one parent is ex ante optimal only if that parent values child quality sufficiently more than their partner.

2. Child quality as a marital specific investment Now suppose that child quality is a marital-specific investment, so that $\partial \Delta(q, \lambda) / \partial q_{i}>0$ and the condition in assumption 1 holds with a strict inequality. The probability of divorce is then partly endogenously determined by parental investments in child quality. To derive the optimal allocation of custody, differentiate the wife's first-order 
condition with respect to her own custodial share:

$$
\begin{aligned}
\frac{\partial}{\partial \lambda_{w}}\left(\frac{\partial V_{w}(q, \lambda)}{\partial q_{w}}\right)= & \frac{1}{2}\left(\theta_{w}-\theta_{h}\right) \frac{\partial}{\partial \lambda_{w}}\left(\frac{\partial \bar{u}(q, \lambda)}{\partial q_{w}}\right)\left(1-G\left(\phi^{*}\right)\right) \\
& +\theta_{w} \frac{\partial}{\partial \lambda_{w}}\left(\frac{\partial \bar{u}(q, \lambda)}{\partial q_{w}}\right) G\left(\phi^{*}\right) \\
& -\frac{1}{2} h^{\prime}\left(\phi^{*}\right) \frac{\partial}{\partial \lambda_{w}}\left(\frac{\partial S}{\partial q_{w}}\right)+\frac{1}{2} g\left(\phi^{*}\right) \frac{\partial}{\partial \lambda_{w}}\left(\frac{\partial S}{\partial q_{w}}\right) S .
\end{aligned}
$$

The last two terms are the new incentive effects introduced by endogenous divorce. First, as the wife has more custody, the private gains from marriage are less sensitive to her investment. In other words, by having more custody, the trade-off in marriage between the benefits from child quality and those from private gains is less severe. This causes the wife's investment to increase as she has more custody.

Second, giving more ex post custody to the wife reduces the marginal effect her investment has on the surplus to be bargained over. This follows from assumption A1 that investment returns are higher in marriage than in divorce. Hence if the wife has more custody, the impact of her investment on keeping the marriage intact is reduced, which lowers her incentive to invest in child quality during marriage. This 'endogenous divorce effect' causes investment and custody to move in opposite directions.

If the second of these new effects is weaker than the first, the net effect of endogenous divorce on investment incentives is that spouses prefer to have more own custody, all else equal. Hence the set of couples who find it optimal to have joint custody is larger than the set defined by (14).

Note however that the set of couples for whom joint custody is optimal decreases in the size of the surplus to be bargained over, $S$-either as spouses' joint valuation of child quality increases, or as divorce costs increase. This is because the strength of the endogenous divorce effect increases in these terms. $^{14}$

As spouses' joint valuation of child quality rises, the couple is more likely to remain married, all else equal. The endogenous divorce effect implies that both place less weight on having more custody, and more weight on giving the high-valuation spouse greater custody, all else equal. The schedule labelled $F F$ in Figure 2 shows the optimal allocation of custody in this case.

As spouses' valuation of child quality rises further, the incentive effect introduced by endogenous divorce is further reinforced by the fact that the marriage remains intact with a high probability. In the limit, spouses are concerned only with the ex ante allocation of custody that maximizes the marital surplus. In other words, both spouses find it optimal to grant sole custody to the high-valuation spouse in divorce.

Proposition 3. When child quality is a marital-specific investment, (i) for couples with relatively heterogeneous valuations, the high-valuation spouse optimally has sole custody; for couples with relatively homogeneous valuations, joint custody is optimal; (ii) the set of couples for whom 


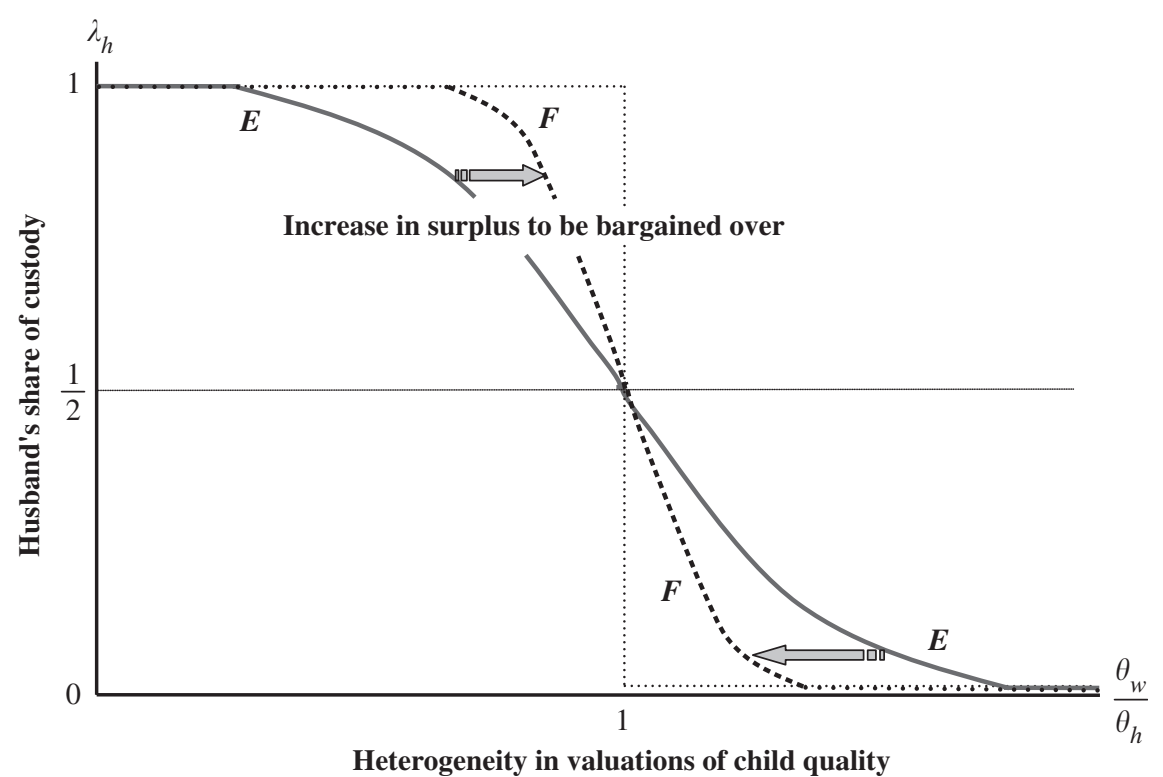

FIGURE 2. The optimal allocation of custody with endogenous divorce.

joint custody is optimal decreases in spouses' joint valuation of child quality.

Joint custody can be optimal for some couples because child quality is a public good, and divorce occurs with positive probability. These conditions generate conflicting investment incentives across parents so that it is optimal for couples with relatively homogeneous valuations of child quality to share custody. ${ }^{15}$

This result builds on Besley and Ghatak (2001). They show that, when investments are made in a public good and divorce cannot occur, then allocating property rights ex post efficiently also maximizes ex ante investment incentives. Hence joint custody is never optimal in their baseline model.

This model makes clear that, when divorce occurs with positive probability, (i) the ex post efficient allocation of custody maximizes ex ante investment incentives only if spousal valuations of child quality are sufficiently heterogeneous; (ii) for couples with relatively homogeneous valuations, joint custody is always optimal; (iii) the high-valuation spouse has the majority share of custody.

In addition, the model highlights that, when child quality is a maritalspecific investment (i) parents have fewer incentives to have more own custody, as this reduces the importance of their investment in keeping the marriage intact; this shifts the allocation of custody towards the high-valuation parent, all else equal; (ii) this effect is stronger for parents with a higher joint valuation of child quality.

\section{Divorce COSTS}

The increased instability of marriage has been associated with a host of factors that have reduced the costs of divorce. These include less social stigma in 
divorce, especially in families with children, increased state support of single parents, and greater wage-earning opportunities for women relative to those available for men. This section makes precise the relationship between divorce costs, the allocation of custody and investment. In doing so, it directly addresses the debate about whether making divorce easier is necessarily bad for children.

\section{Divorce costs and custody}

The optimal allocation of custody depends partly on the size of the surplus to be bargained over. This surplus increases in divorce costs if

$$
\left(\theta_{h}+\theta_{w}\right)\left(\frac{\partial \Delta}{\partial q_{h}} \frac{\partial q_{h}}{\partial c}+\frac{\partial \Delta}{\partial q_{w}} \frac{\partial q_{w}}{\partial c}\right)+1>0
$$

which is more likely to hold if (i) parents' joint valuation of child quality increases; (ii) the marginal return on investment between marriage and divorce increases.

If (16) holds, the effect of divorce costs on the allocation of custody is then very similar to the effect of the joint parental valuation of child quality. When divorce costs are low, the high-valuation parent has the majority custodial share. Couples with relatively heterogeneous valuations have the highvaluation spouse having sole custody, and only parents with relatively homogeneous valuations find it optimal to share custody. As divorce costs fall, for any given couple the high-valuation spouse obtains a smaller share of custody, all else equal. This increases the likelihood of joint custody in the population of married couples.

\section{Divorce costs and investment}

To see how changes in divorce costs affect investments in child quality, differentiate the wife's first-order condition for investment with respect to the divorce cost:

$$
\frac{\partial}{\partial c}\left(\frac{\partial V_{w}(q, \lambda)}{\partial q_{w}}\right)=\frac{1}{2}\left(2 g\left(\phi^{*}\right)+h^{\prime \prime}\left(\phi^{*}\right)+g^{\prime}\left(\phi^{*}\right) \phi^{*}\right) \frac{\partial S}{\partial q_{w}} \leqslant 0 .
$$

Lower divorce costs raise the returns on own investment, increasing investments during marriage. To see the intuition for this, note that a fall in divorce costs has two opposing effects on investment incentives.

On the one hand, the marriage is more unstable and this decreases investment incentives. On the other hand, as the probability of divorce is $G\left(-c-\left(\theta_{h}+\theta_{w}\right) \Delta(q, \lambda)\right)$, with lower divorce costs individual investments have more influence, relative to the divorce cost, on the probability that the marriage remains intact. This endogenous divorce effect implies that spouses have higher incentives to invest when divorce costs are low.

The latter effect captures the intuition that when divorce costs are high, and divorce is endogenously determined by investments themselves, the couple is effectively locked into marriage, irrespective of their individual actions. Hence they have less incentives to make marriage-specific investments, all else equal. 
Overall this effect dominates, so that investments in child quality decrease as divorce costs rise. ${ }^{16}$

\section{Discussion}

The results in this section speak directly to the debate on the effect of making divorce easier on children. The model makes precise three channels through which divorce costs affect child welfare.

First, lower divorce costs make divorce more likely, all else equal, and this may lower child welfare for those children involved in divorce. The empirical evidence, summarized in Amato and Booth (1997), is consistent with this being true for the average divorcée and child.

Second, conditional on divorce, joint custody is more likely to be optimal when divorce costs fall, so that children retain contact with both parents. This can improve child welfare in divorce (Beller and Graham 1993; Del Boca and Ribero 1998).

Third, for a given population of married couples, making divorce easier leads to higher levels of investments in child quality because this increases the commitment value of investments within marriage.

Moreover, a key aspect of marriage is its role in the assignment of custodial rights over children. By default, women are vested with custodial rights to their children while men typically acquire such rights through marriage. Hence unfavourable rules for custody allocation in divorce, from a woman's point of view, may also impact the extent to which women agree to marry in the first place (Edlund 2002).

In general, then, lower divorce costs are likely to have ambiguous general equilibrium effects on child welfare. Identifying the direction and magnitude of these effects remains a challenging area for future research. Certainly, policymakers have been concerned with the decline in the traditional family. A raft of pro-marriage policies have been introduced across the United States. These include media campaigns, the re-introduction of covenant marriages and the removal of marriage penalties in tax codes and Medicaid programmes (Gardiner et al. 2002).

Finally, the model also makes precise that a reduction in the costs of divorce changes the probability of divorce through two channels:

$$
\frac{\mathrm{d} G\left(\phi^{*}\right)}{\mathrm{d} c}=-g\left(\phi^{*}\right)\left[1+\left(\theta_{h}+\theta_{w}\right)\left(\frac{\partial \Delta}{\partial q_{h}} \frac{\partial q_{h}}{\partial c}+\frac{\partial \Delta}{\partial q_{w}} \frac{\partial q_{w}}{\partial c}\right)\right]
$$

On the one hand, it is less costly to divorce, so divorce becomes more likely. On the other hand, spouses invest more in child quality, which decreases the likelihood of marital breakdown. Empirical identification of the causal effect of divorce cost on the likelihood of divorce therefore needs to take account of the endogenous response of spouses in changing investments into marital-specific capital, caused by the change in divorce cost. Not doing so will typically lead to the estimated effect of divorce costs being underestimated. ${ }^{17}$ 


\section{CONCLUSION}

One million children are involved in divorce cases each year in the United States. As is now well established, the living arrangements of children in divorce, and contact time with each parent, are key determinants of children's long-run wellbeing (del Boca and Ribero 1998).

The process by which custody is decided by parents in divorce is complex and is likely to involve their bargaining simultaneously over custody, monetary transfers and property. This paper establishes a benchmark against which such actual custody decisions can be evaluated. In particular, the allocation of child custody is modelled as being decided ex ante as part of the marital contract. This allocation of custody maximizes spousal investments into child quality and minimizes the probability of divorce, all else equal. If child welfare increases in parental investments or decreases when parents break up, then determining the allocation of custody ex ante is consistent with the prevailing legal doctrine of allocating custody in the best interests of the child'.

I have developed a model of marriage in which spouses decide how much to each invest in child quality during marriage, and the allocation of child custody should they divorce. The allocation of custody determines the share of the marital surplus that each spouse appropriates in marital bargaining, which in turn influences spouses' investment incentives. The allocation of custody therefore has both distributional and efficiency consequences within marriage.

The model emphasizes two features of marriage: (i) spouses are unable to specify the investments they will make during marriage as part of any marital contract; (ii) the probability of divorce is determined endogenously by parental investments themselves.

I derived the Nash equilibrium investments and ex ante optimal allocation of custody. The model then makes precise three channels through which making divorce easier affects child welfare: investments into child quality during marriage, the likelihood of divorce, and the allocation of custody if divorce occurs.

This paper suggests three avenues of future research in the law and family economics literatures. First, when marital bargains are subject to renegotiation, the allocation of custody has both efficiency and distributional consequences for married couples. Although it has long been recognized that transaction costs exist in marriage (Ben-Porath 1980; Pollak 1985), the workhorse unitary and Nash bargaining economic models of the family do not account for this. In contrast, the model developed here explicitly models such costs, in the form of actions taken within marriage being non-verifiable to third parties. Further opening up the black box of household decision-making in the presence of transaction costs remains a rich area for future research. ${ }^{18}$

Second, the paper sheds light on why couples are increasingly writing premarital contracts. Spouses may prefer to use such agreements precisely to 'tie their hands', and reduce the possibility of ex post renegotiation. Legal theorists have put forward the case for the enforcement of marital contracts ('private ordering') within marriage (Mnookin and Kornhauser 1979; Ramseyer 1998), precisely arguing that greater marriage specific investments would be made as a result. 
However, courts are typically observed not to enforce such marital contracts, for two reasons. First, agreements made at the time of marriage may not necessarily take children into account. While parents can bargain away their own rights, they cannot bargain away those of their (potentially unborn) children, which the court has an obligation to protect. Second, the bargaining powers of spouses at the time an agreement is reached may not be the same as when the agreement needs to be enforced. This is especially so given that the timing of marital-specific investments during marriage may differ across husbands and wives.

Both issues need to be considered to understand whether children are unambiguously better off if marital contracts are enforced.

Finally, Becker and Murphy (1988) have argued that many family policy interventions replicate the efficient outcomes that would be reached if children had a voice in household decision-making. A broad research agenda analysing if and how aspects of family policy can overcome the inefficiencies caused by limits to marital contracting remains to be addressed.

\section{APPENDIX: PROOFS}

\section{Proof of Proposition 1}

Spouse $i$ chooses their investment to maximize the value of their outside option and their share of the expected surplus created by marriage over divorce:

$$
\begin{aligned}
\max _{q_{i}} V_{i}(q, \lambda)= & \max _{q_{i}}\left(x_{i}+\theta_{i} \bar{u}(q, \lambda)-\frac{1}{2} c\right) \\
& +\frac{1}{2}\left[h\left(\phi^{*}\right)+\left(1-G\left(\phi^{*}\right)\right)\left(\left(\theta_{h}+\theta_{w}\right) \Delta(q, \lambda)+c\right)\right] .
\end{aligned}
$$

The first term is the divorce payoff net of divorce costs, which is concave in $q_{i}$. To ensure that $V_{i}(q, \lambda)$ is concave in $q_{i}$ it is therefore sufficient to show that

$$
h\left(\phi^{*}\right)+\left(1-G\left(\phi^{*}\right)\right)\left(\left(\theta_{h}+\theta_{w}\right) \Delta(q, \lambda)+c\right)
$$

is concave in $q_{i}$. The first and second derivatives of this are

$$
\begin{aligned}
& {\left[h^{\prime}\left(\phi^{*}\right)-\left(1-G\left(\phi^{*}\right)\right)+\phi^{*} g\left(\phi^{*}\right)\right] \frac{\partial \phi^{*}}{\partial q_{i}}} \\
& {\left[h^{\prime}\left(\phi^{*}\right)-\left(1-G\left(\phi^{*}\right)\right)+\phi^{*} g\left(\phi^{*}\right)\right] \frac{\partial^{2} \phi^{*}}{\partial q_{i}^{2}}+\left[h^{\prime \prime}\left(\phi^{*}\right)+2 g\left(\phi^{*}\right)+\phi^{*} g^{\prime}\left(\phi^{*}\right)\right]\left(\frac{\partial \phi^{*}}{\partial q_{i}}\right)^{2}}
\end{aligned}
$$

As $\partial \phi^{*} / \partial q_{i}=-\left(\theta_{h}+\theta_{w}\right)\left(\partial \Delta / \partial q_{i}\right)<0 \quad$ and $\quad \partial^{2} \phi^{*} / \partial q_{w}^{2}=-\left(\theta_{h}+\theta_{w}\right)\left(\partial^{2} \Delta / \partial q_{i}^{2}\right)>0$, sufficient conditions to ensure that the second order condition is negative are

$$
\begin{aligned}
& h^{\prime \prime}\left(\phi^{*}\right)+2 g\left(\phi^{*}\right)+\phi^{*} g^{\prime}\left(\phi^{*}\right) \leqslant 0, \\
& h^{\prime}\left(\phi^{*}\right)-\left(1-G\left(\phi^{*}\right)\right)+\phi^{*} g\left(\phi^{*}\right) \leqslant 0 .
\end{aligned}
$$

The first condition holds if

$$
\phi^{*} \leqslant-\left(\frac{2 g\left(\phi^{*}\right)+h^{\prime \prime}\left(\phi^{*}\right)}{g^{\prime}\left(\phi^{*}\right)}\right)<0
$$

and $g^{\prime}\left(\phi^{*}\right)>0$. These are assumptions A2 and A4, respectively. Note that, as $\phi$ is $\log$ concavely distributed, the right-hand side in (A1) is negative, so the total private gains in the marginal marriage are negative.

(C) The London School of Economics and Political Science 2006 
The following condition ensures that second condition above is satisfied:

$$
h^{\prime}\left(\phi^{*}\right) \leqslant\left(1-G\left(\phi^{*}\right)\right)
$$

This is assumption A3, and also ensures the first derivative of (A0) is increasing in $q_{i}$. Namely, the expected gain from marriage conditional on the marriage remaining intact is increasing in the surplus to be bargained over. Assumptions A2-A4 together ensure that $V_{i}(q, \lambda)$ is concave in each investment.

The ex ante payoffs, $V_{i}(q, \lambda)$, are continuous in $\left(q_{h}, q_{w}\right)$, and the strategy space for spouse $i$ is a non-empty compact subset of $\Re^{+}$, as the cost of investing is positive and finite. Hence if assumptions A1-A4 hold, $V_{i}(q, \lambda)$ is concave in $q_{i}$. By the GlicksbergFan theorem, there then exists at least one pure-strategy Nash equilibrium in parental investments.

\section{Proof of Proposition 2}

Rewrite the wife's investment choice problem as

$$
\begin{aligned}
\max _{q_{w}}\left(x_{w}+\theta_{w} \bar{u}(q, \lambda)-\frac{1}{2} c\right) G\left(\phi^{*}\right)+\frac{1}{2} h\left(\phi^{*}\right) \\
+\frac{1}{2}\left[\left(\theta_{h}+\theta_{w}\right) u+\left(\theta_{w}-\theta_{h}\right) \bar{u}\right]\left[1-G\left(\phi^{*}\right)\right] .
\end{aligned}
$$

The first-order condition is

$$
\begin{aligned}
\frac{1}{2} h^{\prime}\left(\phi^{*}\right) \frac{\partial \phi^{*}}{\partial q_{w}}+\frac{1}{2}\left[\left(\theta_{h}+\theta_{w}\right) \frac{\partial u}{\partial q_{w}}+\left(\theta_{w}-\theta_{h}\right) \frac{\partial \bar{u}}{\partial q_{w}}\right]\left[1-G\left(\phi^{*}\right)\right] \\
-\frac{1}{2}\left[\left(\theta_{h}+\theta_{w}\right) u+\left(\theta_{w}-\theta_{h}\right) \bar{u}\right] g\left(\phi^{*}\right) \frac{\partial \phi^{*}}{\partial q_{w}}+\theta_{w} \frac{\partial \bar{u}}{\partial q_{w}} G\left(\phi^{*}\right) \\
+\left[\theta_{w} \bar{u}-\frac{1}{2} c\right] g\left(\phi^{*}\right) \frac{\partial \phi^{*}}{\partial q_{w}}=p .
\end{aligned}
$$

There are four sources of investment incentive arising from having more own custody. If the marginal returns to investment in marriage over divorce, $\partial \Delta(q, \lambda) / \partial q_{i}$, are small, the probability of divorce is approximately $G(-c)$ and the wife's first-order condition reduces to

$$
\frac{1}{2}\left(\left(\theta_{h}+\theta_{w}\right) \frac{\partial u}{\partial q_{w}}+\left(\theta_{w}-\theta_{h}\right) \frac{\partial \bar{u}}{\partial q_{w}}\right)[1-G(-c)]+\theta_{w} \frac{\partial \bar{u}}{\partial q_{w}} G(-c)=p .
$$

The effect of giving the wife more custody on her investment incentives is

$$
\frac{1}{2}\left(\theta_{w}-\theta_{h}\right) \frac{\partial}{\partial \lambda_{w}}\left(\frac{\partial \bar{u}}{\partial q_{w}}\right)[1-G(-c)]+\theta_{w} \frac{\partial}{\partial \lambda_{w}}\left(\frac{\partial \bar{u}}{\partial q_{w}}\right) G(-c) .
$$

The first term implies that spouses prefer the high-valuation parent to have sole custody. This maximizes the surplus to be bargained over conditional on the marriage remaining intact. The second term implies that spouses prefer to have more own custody to maximize the returns on their investment in divorce.

To maximize spouses's ex ante payoffs, custody is allocated to equate the marginal returns across spouses.

If parents have homogeneous valuations, then equating marginal incentives implies

$$
\frac{\partial}{\partial \lambda_{w}}\left(\frac{\partial \bar{u}}{\partial q_{w}}\right)=\frac{\partial}{\partial \lambda_{h}}\left(\frac{\partial \bar{u}}{\partial q_{h}}\right)
$$

which is satisfied if $\lambda=\frac{1}{2}$ so custody is equally shared.

(C) The London School of Economics and Political Science 2006 
Suppose there exists some degree of heterogeneity in valuations at which the wife's investment incentive increases in her own custodial share. This occurs when (A3) is positive, so that $\theta_{w} / \theta_{h} \geqslant[1-G(-c)] /[1+G(-c)]$. Similarly, if the husband's investment incentives are increasing in his custodial share, it must be that $\theta_{w}$ $\theta_{h} \leqslant[1+G(-c)] /[1-G(-c)]$. Hence both spouses' investment incentives are increasing with more own custody for the set of couples that lie in (14) in the main text. These incentives are traded off by giving both spouses some custodial share. The highvaluation spouse has the strictly greater share because the marginal effect on investment of their having more own custody is greater than for the low-valuation spouse. Finally, note that

$$
\frac{\partial}{\partial c}\left(\frac{1-G(-c)}{1+G(-c)}\right)=\frac{[1+G(-c)] g(-c)+[1-G(-c)] g(-c)}{[1+G(-c)]^{2}}>0
$$

and

$$
\frac{\partial}{\partial c}\left(\frac{1+G(-c)}{1-G(-c)}\right)=\frac{-[1-G(-c)] g(-c)-[1+G(-c)] g(-c)}{[1-G(-c)]^{2}}<0,
$$

so the set of couples for whom joint custody is optimal is decreasing in divorce costs.

\section{Proof of Proposition 3}

When child quality is a marital-specific investment, the first-order condition for the wife's investment choice is

$$
\begin{aligned}
\frac{\partial}{\partial \lambda_{w}}\left(\frac{\partial V_{w}(q, \lambda)}{\partial q_{w}}\right)= & \frac{1}{2}\left(\theta_{w}-\theta_{h}\right) \frac{\partial}{\partial \lambda_{w}}\left(\frac{\partial \bar{u}(q, \lambda)}{\partial q_{w}}\right)\left(1-G\left(\phi^{*}\right)\right) \\
& +\theta_{w} \frac{\partial}{\partial \lambda_{w}}\left(\frac{\partial \bar{u}(q, \lambda)}{\partial q_{w}}\right) G\left(\phi^{*}\right)-\frac{1}{2} h^{\prime}\left(\phi^{*}\right) \frac{\partial}{\partial \lambda_{w}}\left(\frac{\partial S}{\partial q_{w}}\right) \\
& +\frac{1}{2} g\left(\phi^{*}\right) \frac{\partial}{\partial \lambda_{w}}\left(\frac{\partial S}{\partial q_{w}}\right) S .
\end{aligned}
$$

Recall that by assumption A5 the allocation of custody has no effect on investment returns on marriage, only in divorce. Hence the above expression simplifies to

$$
\begin{aligned}
\frac{\partial}{\partial \lambda_{w}}\left(\frac{\partial V_{w}(q, \lambda)}{\partial q_{w}}\right)= & \frac{1}{2}\left(\theta_{w}-\theta_{h}\right) \frac{\partial}{\partial \lambda_{w}}\left(\frac{\partial \bar{u}(q, \lambda)}{\partial q_{w}}\right)\left(1-G\left(\phi^{*}\right)\right) \\
& +\theta_{w} \frac{\partial}{\partial \lambda_{w}}\left(\frac{\partial \bar{u}(q, \lambda)}{\partial q_{w}}\right)\left(G\left(\phi^{*}\right)+\frac{1}{2} h^{\prime}\left(\phi^{*}\right)+\frac{1}{2} g\left(\phi^{*}\right) \phi^{*}\right) .
\end{aligned}
$$

The second line of this equation captures the two new effects introduced by endogenous divorce. Note that if $\phi^{*}<-\left(h^{\prime}\left(\phi^{*}\right) / g\left(\phi^{*}\right)\right)$, parental incentives to have more own custody are less than in the case of exogenous divorce. Hence a smaller set of couples will find it optimal to have joint custody, all else equal. The opposite is true if $\phi^{*}>-\left(h^{\prime}\left(\phi^{*}\right) / g\left(\phi^{*}\right)\right)$.

Using the same method as in proposition 2, the set of couples for whom joint custody is optimal is in general given by

$$
\left\{\left(\theta_{h}, \theta_{w}\right): \frac{\theta_{w}}{\theta_{h}} \in\left[\frac{1-G\left(\phi^{*}\right)+S-h^{\prime}\left(\phi^{*}\right)}{1+G\left(\phi^{*}\right)-S+h^{\prime}\left(\phi^{*}\right)}, \frac{1+G\left(\phi^{*}\right)-S+h^{\prime}\left(\phi^{*}\right)}{1-G(-c)+S-h^{\prime}\left(\phi^{*}\right)}\right]\right\} .
$$

(C) The London School of Economics and Political Science 2006 
Note that, from assumption A3, $1-G\left(\phi^{*}\right)+S-h^{\prime}\left(\phi^{*}\right) \geqslant 0$. Joint custody is optimal for this set of couples because the wife's investment moves with her custody if

$$
\frac{\theta_{w}}{\theta_{h}} \geqslant \frac{1-G\left(\phi^{*}\right)+S-h^{\prime}\left(\phi^{*}\right)}{1+G\left(\phi^{*}\right)-S+h^{\prime}\left(\phi^{*}\right)}
$$

and the husband's investment moves with his own custody if

$$
\frac{\theta_{w}}{\theta_{h}} \leqslant \frac{1+G\left(\phi^{*}\right)-S+h^{\prime}\left(\phi^{*}\right)}{1-G(-c)+S-h^{\prime}\left(\phi^{*}\right)}
$$

For couples in (A4), both spouses optimally have some positive custodial share. To see this, consider a couple with valuations such that

$$
\frac{\theta_{w}}{\theta_{h}}>\frac{1+G\left(\phi^{*}\right)-S+h^{\prime}\left(\phi^{*}\right)}{1-G(-c)+S-h^{\prime}\left(\phi^{*}\right)} .
$$

The wife's investment increases with an increment to her custody, and the husband's decreases with an increment to his own custody. Hence both are better off if the wife has sole custody. To understand which spouse has the majority share of custody, consider the following cases.

(i) $1+G\left(\phi^{*}\right)>S-h^{\prime}\left(\phi^{*}\right)>-G\left(\phi^{*}\right)$. In this region $h^{\prime}\left(\phi^{*}\right)>S$, so the incentives to invest arising from the happiness effect in marriage outweigh the disincentives arising from the endogenous divorce effect. The net effect of these incentives is similar to the case where divorce occurs for exogenous reasons, but the set of couples for whom joint custody is optimal is greater than in (14).

(ii) $G\left(\phi^{*}\right)>S-h^{\prime}\left(\phi^{*}\right)>0$. In this region the incentives to invest arising from the endogenous divorce effect dominate those arising from the happiness effect. The net effect of these incentives remains similar to the case where divorce occurs with exogenous probability, except that a smaller set of couples find it optimal to have joint custody compared with (14). At the border of regions (i) and (ii), when $S=h^{\prime}\left(\phi^{*}\right)$, the two new effects arising from endogenous divorce exactly offset each other and the set of couples who optimally choose joint custody is (14).

As the surplus to be bargained over increases further, note that $\lim _{\phi^{*} \rightarrow-\infty} h^{\prime}\left(\phi^{*}\right)=0, \lim _{\phi^{*} \rightarrow-\infty} g\left(\phi^{*}\right) \phi^{*}=0$ and $\lim _{\phi^{*} \rightarrow-\infty} G\left(\phi^{*}\right)=0$. In other words, the new incentive effects introduced by endogenous divorce are no longer prominent as the marriage remains intact with near certainty. Hence the marginal effect on the wife's investment incentives from having more own custody is

$$
\frac{\partial}{\partial \lambda_{w}}\left(\frac{\partial V_{w}(q, \lambda)}{\partial q_{w}}\right)=\frac{1}{2}\left(\theta_{w}-\theta_{h}\right) \frac{\partial}{\partial \lambda_{w}}\left(\frac{\partial \bar{u}(q, \lambda)}{\partial q_{w}}\right) .
$$

The optimal allocation of custody is for the high-valuation spouse to have sole custody. When the marital surplus is large, the couple remain married with near certainty, and so both are better off giving more custody to the spouse who has greater investment incentives in marriage.

\section{ACKNOWLEDGMENTS}

I have benefited from discussions with Oriana Bandiera, Tim Besley, Richard Blundell, Robin Burgess, Leonardo Felli, Marco Francesconi, Yong Kim, Niko Matouschek, Dilip Mookherjee, Michele Piccione, Andrea Prat and Yoram Weiss. I would also like to thank two anonymous referees for useful comments.

(C) The London School of Economics and Political Science 2006 


\section{NOTES}

1. The legal definition of joint custody includes (i) joint physical custody, where both parents share physical and custodial care of the child; (ii) joint legal custody, where both parents retain joint responsibility for the care and control of the child and joint authority to make decisions concerning the child even though the child's primary residence may be with only one parent; (iii) any combination of joint legal and joint physical custody that the court deems to be in the best interests of the child. The model captures aspects of each of these definitions.

2. Relatedly, Rainer (2002) extends the Besley-Ghatak (2001) analysis to consider how investments in property are affected by legal rules on the division of these assets in divorce. In his framework, divorce does not occur.

3. This assumption is without loss of generality. Furthermore, many US state laws on custody emphasize a strong prior in favour of siblings residing together in divorce.

4. The private gains from marriage are not a household public good, and so should not be thought of as marriage quality as normally modelled in the literature. Rather, they capture the individual utility to each spouse of being married relative to being divorced.

5. Courts are reluctant to intervene over parental conduct towards children during marriage, with the obvious exception of abusive behaviour. This includes parental decisions that have direct consequences for child welfare, such as the allocation of resources within the household or where children go to school. Where spouses have written explicit marital contracts, courts have been reluctant to enforce them (Rasmusen and Stake 1998). This begs the question of why an increasing number of couples are writing such contracts, an issue returned to in the conclusion.

6. Becker (1991) cites children as the prime source of marriage-specific capital. The fact that both spouses continue to enjoy benefits from children distinguishes them from most other forms of marital-specific capital.

7. Many commonly used distributions, including the normal distribution, lie within the family of log-concave distributions.

8. As utilities are quasi-linear in $v_{i}$, the probability of divorce depends on the distribution of $\phi=v_{h}+v_{w}$. If individual private gains $\left(v_{h}, v_{w}\right)$ are correlated, this is accounted for in their joint distribution, $G(\phi)$.

9. Note that assumptions A2-A4 relate to the total private gains in the marginal marriage. There exist positive values of $\left(c, \theta_{h}, \theta_{w}\right)$ such that these assumptions hold for all $\phi<0$ within the family of normal distributions. For example, if $\phi \sim N(-1,1), \mathrm{A} 2-\mathrm{A} 4$ are satisfied if $c \geqslant 2.5 \theta_{h} \geqslant 0, \theta_{w} \geqslant 0$.

10. However, as $1-G\left(\phi^{*}\right)>h^{\prime}\left(\phi^{*}\right)$ by assumption $\mathrm{A} 3$, this disincentive never offsets the first two incentives to invest.

11. This is one of the key insights of Besley and Ghatak (2001), namely that ex ante investment incentives to both parties are maximized by allocating the public good to the high-valuation party ex post. This is in contrast to the standard GHM framework, where investments are made into a private good, and investment incentives and property rights move together for each party. The intuition for the result is that for a public good even the non-owning party continues to enjoy benefits from the good in divorce. Hence both parties have incentives to allocate property rights to maximize investment incentives in the relationship.

12. Consider a couple for whom $\left(\theta_{w} / \theta_{h}\right)<[1-G(-c)] /[1+G(-c)]<1$. Granting the husband incrementally more custody increases his investment incentives, and decrease his wife's. As the husband values child quality more than his wife, it is optimal for him to have sole custody. A similar argument applies for couples for whom $\left(\theta_{w} / \theta_{h}\right)>[1+G(-c)] /$ $[1-G(-c)]>1$. Only for couples with relatively homogeneous valuations will joint custody be optimal.

13. The result is robust to assuming that parental valuations of child quality differ across marital states, as in Francesconi and Muthoo (2003). Suppose $U_{i}^{D}(q, \lambda)=y_{i}+\delta_{i} \bar{u}(q, \lambda)$. From assumption A5, as the allocation of custody affects investment returns only in divorce and not in marriage, the set of couples that find it optimal to have joint custody is

$$
\left\{\left(\delta_{h}, \delta_{w}\right): \frac{\delta_{w}}{\delta_{h}} \in\left[\frac{1-G(-c)}{1+G(-c)}, \frac{1+G(-c)}{1-G(-c)}\right]\right\} .
$$

A similar argument can be made for the other results on custody.

14. To see this formally, note that

$$
\frac{\partial}{\partial S}\left(g\left(\phi^{*}\right) S\right)=g^{\prime}\left(\phi^{*}\right) \phi^{*}+g\left(\phi^{*}\right) .
$$


From A4 we have that $\phi^{*} \leqslant-\left\{\left[2 g\left(\phi^{*}\right)+h^{\prime \prime}\left(\phi^{*}\right)\right] / g^{\prime}\left(\phi^{*}\right)\right\}$, which implies that $\phi^{*} \leqslant$ $-\left(g\left(\phi^{*}\right) / g^{\prime}\left(\phi^{*}\right)\right)$ as $h^{\prime \prime}\left(\phi^{*}\right) \geqslant 0$ by the log-concavity of $g(\phi)$. Hence $(\partial / \partial S)\left(g\left(\phi^{*}\right) S\right) \leqslant 0$, so investment and custody move in opposite directions as $S$ increases.

15. This contrasts with other explanations of why joint ownership is optimal in the literature on non-contractible investments into a private good. For example, Rajan and Zingales (1998) argue that, if investment leads to greater specialization within a relationship, the returns to outside options fall in own investment. Hence parties appropriate a lower share of the marginal benefits in the current relationship because their position is weakened in ex post renegotiation. Each party is therefore better off by not owning the asset so that they do not lock themselves into the current relationship. Joint ownership can then be optimal. Alternatively, de Meza and Lockwood (1998) present a model in which parties use outside options bargaining, so that if one party's divorce payoff binds after the investment is made then the other party appropriates all of the surplus. Hence investing in the relationship increases the likelihood that a party's own outside option binds in renegotiation, and they do not appropriate the returns on their own investment. Joint ownership can again be optimal. In both cases, joint ownership is driven by the fact that, by investing, the individual appropriates a smaller share of the surplus. This is not the driving force in the model presented here.

16. In a standard Nash bargaining model of the household, divorce costs have no affect on investments, as they affect neither the marginal cost nor the marginal benefit of investing.

17. This may explain why existing empirical evidence on the effect of divorce costs on the probability of divorce is very mixed. For example, it is often argued that the introduction of no-fault divorce reduced divorce costs. However, the empirical evidence on the causal effect of no-fault divorce laws on divorce rates remains mixed; Mechoulan (2002) summarizes the conflicting findings in the literature.

18. Peters (1986), Lundberg and Pollak (2001) and Murphy (2002) also develop models of household behaviour in which limits on marital contracting lead to inefficient outcomes.

\section{REFERENCES}

Amato, P. R and Booth, A. (1997). A Generation at Risk: Growing Up in an Era of Family Upheaval. Cambridge, Mass.: Harvard University Press.

BeCKer, G. S. (1973). A theory of marriage: part I. Journal of Political Economy, 81, 813-46. (1974). A theory of marriage: part II. Journal of Political Economy, 82, S11-S26. (1991). A Treatise on the Family, (enlarged edn). Cambridge, Mass.: Harvard University Press.

and Murphy, K. M. (1988). The family and the state. Journal of Law and Economics, 31, $1-18$.

- and Tomes, N. (1986). Human capital and the rise and fall of families. Journal of Labor Economics, 4, S1-S39.

- LANDEs, E. M. and Micheal, R. T. (1977). An economic analysis of marital instability. Journal of Political Economy, 85, 1141-88.

Beller, A. and Graham, J. (1993). Small Change: The Economics of Child Support. New Haven: Yale University Press.

Ben-Porath, Y. (1980). The F-connection: families, friends and firms and the organization of exchange. Population and Development Review, 6, 1-30.

Besley, T. J. and GHATAK, M. (2001). Government versus private ownership of public goods. Quarterly Journal of Economics, 116, 1343-72.

Brown, M. and FlinN, C. J. (2001). Investment in child quality over marital states. Mimeo, University of Wisconsin, Madison.

Bumpass, L. L., Raley, R. K. and SweEt, J. A. (1995). The changing character of stepfamilies: implications of cohabitation and nonmarital childbearing. Demography, 32, 425-36.

Chitppori, P. A. (1988). Rational household labor supply. Econometrica, 56, 63-90.

DANZIGER, S. and WALDFOGEL, J. (2000). Investing in children: What do we know? What should we do? Centre for the Analysis of Social Exclusion Paper no. 34.

Del BocA, D. and Ribero, R. (1998). Transfers in non-intact households. Structural Change and Economic Dynamics, 9, 469-78.

DE MEZA, D. and LocKwood, B. (1998). Does asset ownership always motivate managers? Outside options and the property rights theory of the firm. Quarterly Journal of Economics, 113, 361-86.

EdLund, L. C. (2002). Marriage. Mimeo, Columbia University, New York. 
Francesconi, M. and Muthoo, A. (2003). An economic model of child custody. Mimeo, University of Essex.

Gardiner, K. N., Fishman, M. E., Nikolov, P., Glosser, A. and Laud, S. (2002). State Policies to Promote Marriage, Final Report. Falls Church, Va: The Lewin Group.

Grossman, S. and HART, O. (1986). The costs and benefits of ownership: a theory of vertical and lateral integration. Journal of Political Economy, 94, 691-719.

HALONEN, M. (2002). Reputation and the allocation of ownership. Economic Journal, 112, 539-58.

Hart, O. (1995). Firms, Contracts and Financial Structure. Oxford: Oxford University Press. - and Moore, J. (1990). Property rights and the theory of the firm. Journal of Political Economy, 98, 1119-58.

Lillard, L. A. and Waite, L. J. (1991). Children and marital disruption. American Journal of Sociology, 96, 930-53.

Lundberg, S. and Pollak, R. A. (1993). Separate spheres bargaining and the marriage market. Journal of Political Economy, 101, 988-1010.

- and (2001). Efficiency in marriage. NBER Working Paper no. 8642.

MCElroy, M. and Horney, M. (1981). Nash-bargained decisions: towards a generalization of the theory of demand. International Economic Review, 22, 333-49.

Mechoulan, S. (2002). Divorce laws and economics: what have we learnt? Mimeo, University of Toronto.

Mnookin, R. H. and Kornhauser, L. (1979). Bargaining in the shadow of the law: the case of divorce. Yale Law Journal, 88, 950-97.

Mulligan, C. B. (1997). Parental Priorities and Economic Inequality. Chicago: University of Chicago Press.

Murphy, R. D. (2002). A good man is hard to find: marriage as an institution. Journal of Economic Behavior and Organization, 47, 27-53.

Peters, E. H. (1986). Marriage and divorce: informational constraints and private contracting. American Economic Review, 76, 437-54.

Pollak, R. A. (1985). A transaction cost approach to families and households. Journal of Economic Literature, 23, 581-608.

RAINER, H. (2002). Should we write pre-nuptial contracts? Mimeo, University of Essex.

RAJAN, R. and Zingales, L. (1998). Power in a theory of the firm. Quarterly Journal of Economics, 113, 387-432.

RAMSEYER, J. M. (1998). Towards contractual choice in marriage. Indiana Law Journal, 73, 511-16.

RASMusen, E. and StAKe, J. E. (1998). Lifting the veil of ignorance: personalizing the marriage contract. Indiana Law Journal, 73, 453-502.

WEISS, Y. and WiLLis, R. J. (1985). Children as collective goods and divorce settlements. Journal of Labor Economics, 3, 268-92.

- and (1997). Match quality, new information, and marital dissolution. Journal of Labor Economics, 15, S293-S99.

Willis, R. J. (1973). A new approach to the economic theory of fertility behavior. Journal of Political Economy, 81, S14-S64. 